\title{
Analysis of a High Temperature Gas-Cooled Reactor Powered High Temperature Electrolysis Hydrogen Plant
}

\section{IMECE 2010}

M. G. McKellar

E. A. Harvego

A. M. Gandrik

\section{November 2010}

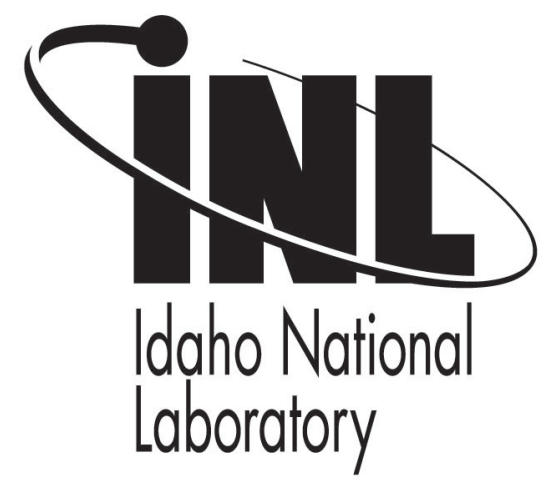

This is a preprint of a paper intended for publication in a journal or proceedings. Since changes may be made before publication, this preprint should not be cited or reproduced without permission of the author. This document was prepared as an account of work sponsored by an agency of the United States Government. Neither the United States Government nor any agency thereof, or any of their employees, makes any warranty, expressed or implied, or assumes any legal liability or responsibility for any third party's use, or the results of such use, of any information, apparatus, product or process disclosed in this report, or represents that its use by such third party would not infringe privately owned rights. The views expressed in this paper are not necessarily those of the United States Government or the sponsoring agency. 


\title{
ANALYSIS OF A HIGH TEMPERATURE GAS-COOLED REACTOR POWERED HIGH TEMPERATURE ELECTROLYSIS HYDROGEN PLANT
}

\author{
M. G. McKellar, E. A. Harvego, A. M. Gandrik \\ Idaho National Laboratory \\ Idaho Falls, ID 83415, USA
}

\begin{abstract}
An updated reference design for a commercial-scale hightemperature electrolysis (HTE) plant for hydrogen production has been developed. The HTE plant is powered by a hightemperature gas-cooled reac tor (HTGR) whose configuration and operating conditions are based on the latest design parameters planned for the Next Generation Nuclear Plant (NGNP). The current HTGR reference design specifies a reactor power of $600 \mathrm{MWt}$, with a primary system pressure of 7.0 MPa, and reactor inlet and outlet fluid te mperatures of $322^{\circ} \mathrm{C}$ and $750^{\circ} \mathrm{C}$, res pectively. The reactor heat is used to produce heat and electric power for the HTE plant. A Rankine steam cycle with a powe $r$ conversion efficiency of $44.4 \%$ was used to provide the electric power. The electrolysis unit used to produce hydrogen includes 1.1 million cells with a p er-cell active area of $225 \mathrm{~cm}^{2}$. The refere nce hydrogen production plant operates at a system pressure of 5.0 MPa, and utilizes a steam-sweep system to rem ove the exc ess oxygen that is evolved on the anode (oxygen) side of the electrolyzer. The overall system thermal-to-hydrogen production efficiency (based on the higher heating value of the produced hydrogen) is $42.8 \%$ at a hydrogen production rate of $1.85 \mathrm{~kg} / \mathrm{s}$ (66 million SCFD) and an oxygen production rate of $14.6 \mathrm{~kg} / \mathrm{s}$ (33 million SCFD). An economic analysis of this plant was performed with realistic financial and cost esti mating The results of the economic analysis dem onstrated that the HTE hydrogen production plant driven by a hi gh-temperature helium-cooled nuclear power plant can deliver hydrogen at a competitive cost. A cost of $\$ 3.03 / \mathrm{kg}$ of hydrogen was cal culated assuming an internal rate of return of $10 \%$ and a deb t to equity ratio of $80 \% / 20 \%$ for a reactor c ost of $\$ 2000 / \mathrm{kWt}$ and $\$ 2.41 / \mathrm{kg}$ of hydrogen for a reactor cost of $\$ 1400 / \mathrm{kWt}$.
\end{abstract}

\section{INTRODUCTION}

As part of the ongoing activities at Id aho National Laboratory (INL) to investigate the potential for large-scale production of hydrogen using the nuclear-driven high- temperature electrolysis (HTE) process, INL personnel evaluated a number of alternative power cycle concepts coupled in d ifferent ways to alternative HTE process loop designs. This evaluation process led to the development in 2006 of a preliminary design for a hi gh temperature gas-cooled reactor (HTGR) direct Brayton power cycle coupled to an HTE hydrogen production plant that $\mathrm{w}$ as designated as the original INL reference HTE design [1]. The HTGR utilized helium at a reactor outlet temperature of $900^{\circ} \mathrm{C}$ to provide electricity and high-temperature process heat for $\mathrm{t}$ he electrolytic hydrogen production process. This initial referen ce design underwent extensive analyses and reviews to refine and optimize the concept. In addition, economic analyses were performed to determine the approximate cost for the commercial production of hydrogen at large scales [2]. The results of these studies, along with the testing and analyses of la rge numbers of solid oxide electrolysis cells, led to the selection in 2009 of HTE as the preferred concept in the U.S. Department of Ener gy hydrogen technology down-selection process [3]. T he earliest anticipated applications for the NGNP are not expected to require outlet temperatures as $\mathrm{h}$ igh as $950^{\circ} \mathrm{C}$. Therefore, the outlet temperature of the reference design was reduce $\mathrm{d}$ to $750^{\circ} \mathrm{C}-800^{\circ} \mathrm{C}$ to take advantage of simplified design and codification strategies that result from the reduction.

A new I NL reference design has been developed and evaluated using the HYSYS process analysis software. Initial HYSYS evaluations were also performed for a Rankine steam power cycle intended for the production of the electricity and process heat required by the INL reference HTE hy drogen production process. The optimized power cycle design was then coupled to the new INL reference HTE hyd rogen production process, and the HYSYS models of the integrated systems were optimized to maximize the total hydrogen production rates and overall hydrogen production efficiencies for $t$ he integrated power cycle/INL reference hydrogen production concept. This analysis process, along with the resulting optimized reference 
design for the integrated nuclear-driven hydrogen production plant concept, is discussed in this paper.

\section{PROCESS DESCRIPTION}

A steam Rankine power cycle was evaluated as part of the development of the new INL Reference HTE hydrogen production process. The power cycle was ass umed to be powered by an HTGR whose configuration and operating conditions are based on the latest design parameters planned for the Next Generation Nuclear Plant (NGNP). The current HTGR reference design specifies a reactor power of $600 \mathrm{MWth}$ with a primary system pressure of $7.0 \mathrm{MPa}$ and reactor inlet and outlet fluid temperatures of 322 and $750^{\circ} \mathrm{C}$, respectively. Using these reactor operating conditions, the power cycle was optimized using Hyprotech's HYSYS.Plant process analysis software [4] to maximize power cycle efficiency prior to coupling the power cycle to the new INL Reference HTE hydrogen production process.

The following assumptions were made for this analysis:

- The minimum approach temperature for most of the heat exchangers is $25^{\circ} \mathrm{C}$. This approximates heat exchangers with efficiencies near $95 \%$.

- The high temperature recuperating heat exchangers in the high temperature electrolysis process have minimum approach temperatures of $20^{\circ} \mathrm{C}$ because they have relatively smaller temperature differences between the inlet and outlet conditions.

- The primary and secondary helium loops and the HTE loop have heat exchanger pressure drops equal to $2 \%$ of the average pressure in the loops.

- The power cycle components have $2 \%$ pressures drops based on inlet pressures, except for the steam generator and the reheater of the Rankine cycle, which have a $10 \%$ pressure drop.

- The primary and secondary circulators have adiabatic efficiencies of $90 \%$.

- The hydrogen recirculator and all pumps have adiabatic efficiencies of $75 \%$.

The Rankine steam cycle has three $\mathrm{t}$ urbines and seven feedwater heaters. The inlet pressure and temperature into the high pressure turbine is $24 \mathrm{MPa}$ and $593^{\circ} \mathrm{C}$. The pressure in the condenser is 1 psia. The Rankine high pressure turbine, intermediate pressure turb ine, and low pressure turbine have adiabatic efficiencies of 85,90 , and $80 \%$, respectively.

Figure 1 is a process model of the HTE process coupled with the Rankine Steam cycle. The optimized reference design for the HTE hydrogen production process operates at a system pressure of $5 \mathrm{MPa}$ and uses a steam sweep system rather than the air sweep system used in the original INL reference design to remove oxygen from the anode side of the electrolyzer. This change was made from the original reference design so that the oxygen product gas, which represents a valuable commodity, can be recovered by condensing the steam and recovering the dry oxygen product gas for later sale.

The HTGR (depicted on the left side of the process flow sheet in Figure 1) provides both electricity and process heat to drive the HTE process. The Rankine steam cycle use $d$ to produce electricity to drive $t$ he electrolysis process is modeled in a sub-flow sheet designated by the letter " $T$ " on the left side of the process flow sheet in Figure 1. An AC to DC power conversion efficiency of $96 \%$ was assumed for supplying DC power to the electrolyzer.

Process heat from the HTGR (which represents only about $10 \%$ of the total reactor power) is transferred from the primary loop through an IHX to an intermediate helium loop, and then to the two steam generators (SG1 and SG2) shown in Figure 1. The use of the intermediate loop between the reactor primary system and the HTE process was i ncluded in the new INL reference design as an added barrier to minimize the potential for tritium migration from the primary system, and potential tritium contamination of the HTE product hydrogen.

Feed water for the HTE process (Water In) is raised to the system operating pressure of $5 \mathrm{MPa}$ by a pump, where it is then mixed with recycled water condensed from the hydrogen product water sep aration tank. The water stream is th en partially vaporized in the recuperator (Low Temp Steam/H2 Recup) which recovers heat from the post-electrolysis process. The low quality feed stream then enters a steam generator (SG2) where the remaining water is vaporized and the steam is heated to approximately $100^{\circ} \mathrm{C}$ below the electrolysis operating temperature of $800^{\circ} \mathrm{C}$. Downstream of the steam generator, at $\mathrm{M} 12$, the steam is mixed with recycled hydrogen product gas. A fraction of the product gas is recycled in $t$ his way in order to assure that reducing conditions are main tained on the steam/hydrogen electrode. The resulting steam and hydrogen mixture (approximately 10\% hydrogen) then passes through a second post-electrolysis process recuperator and a gas-fired or electric heater to raise its temperature to the desired electrolysis operating temperature of $800^{\circ} \mathrm{C}$.

The process stream then en ters the electrolyzer, where oxygen is electrolytically removed from the steam, producing hydrogen and oxygen. The custom electrolyzer module developed at INL for direct incorporation into the HYSYS process analysis code is described in more detail further in this paper.

Downstream of the electrolyzer, the hydrogen-rich product stream (approximately $70 \mathrm{~mol} \%$ hydrogen) passes back through the two post-electrolysis recuperators where the product stream is cooled and, as described earlier, the recovered heat is used to heat the inlet process stream to near the desired electrolysis process temperature. The product stream is then further cooled at the water separation tank, where the majority of any residual steam is co ndensed and separated, yielding the dry hydrogen product. The cooled product stream is sp lit at T20 and a fraction of the product gas is recycled into the inlet process stream as di scussed previously. A recirculating blower is 
required to re pressurize the hydrogen recycle stream to the upstream pressure at M12.

As mentioned earlier, the new INL reference design uses a steam sweep system to re move the e xcess oxygen that is evolved on the anode side of the electrolyzer. In the steam sweep system, the inlet water (Sweep Water In) is raised to the system operating pressure by the sweep pump, and then mixed with condensed water recirculated back from the water/oxygen separation tank at M4. The recirculation of condensed water from the oxygen product stream significantly reduces the net amount of water needed to operate the steam sweep system. After leaving the M4 mixer, the sweep water passes through a recuperator (Sweep L ow Temp Recup), where recovered heat from the sweep system heats and vaporizes the feed water. The superheated steam then pass es through steam generator (SG1), where it is supe rheated to ap proximately $100^{\circ} \mathrm{C}$ below the electrolysis operating tem perature of $800^{\circ} \mathrm{C}$. The steam then passes through a second sweep system recuperator (Sweep Hi Temp Recup) and a gas fired or electric heater where the sweep steam is raised to $800^{\circ} \mathrm{C}$ before entering the electrolyzer stack.

After removing the excess oxygen from the anode of the electrolyzer, the steam /oxygen mixture (50\% oxygen) then passes through the two previously discussed steam sweep system recuperators, where excess heat is recovered and the post-electrolysis steam-oxygen mixture is cooled. The resulting high quality steam-oxygen mixture is then further cooled in the water/oxygen separation tank, where the majority of the water is condensed and recirc ulated back to be combined with the sweep water feed at M4. The relatively dry oxygen product leaving the water/oxygen separation tank at high pressure (4.9 $\mathrm{MPa})$ is then available for immediate use or storage for later use.

The electrolyzer model process flow diagram is shown in Figure 2. The process inlet flow, consisting of steam and hydrogen passes through a conversion reactor where the steam is split into hydrogen and oxygen. The conversion reactor uses a stoichiometric equation for the splitting of water. Based upon the utilization, a specified percentage of the steam is converted. HYSYS calculates the heat of reaction for this conversion, which is shown as the "Electrolysis Heating" energy stream in Figure 2. The hydrogen, oxygen, and steam enter a com ponent splitter labeled Electrodes. The oxygen is split from the other components and exits at the anode stream. The sweep gas mixes with the anode stream and exits as the "Sweep Gas/O2 Out" stream. An embedded spreadsheet is used to calculate the Nernst potential, operating voltage, current and electrolysis power [5]. In this reference case, the boundary conditions are isothermal and a diabatic, which is referred as the thermal neutral point.

\section{ANALYSIS RESULTS}

The HYSYS analysis of the above described new INL reference design coupled to the steam Rankine cycle achieves a hydrogen production rate of $1.85 \mathrm{~kg} / \mathrm{s}$ and an overall hydrogen production efficiency of $42.8 \%$ with a reactor power source of $600 \mathrm{MW}$ th operating at a $\mathrm{r}$ eactor outlet temperature of $750^{\circ} \mathrm{C}$. The overall hydrogen production efficiency is based on the higher heating value of the hydrogen product divided by the total heat input. The total heat input for both cases is the sum of the reactor heat plus the heat needed by the two topping heaters in the HTE loop. The electrolysis stack consists of 1.12 million electrolysis cells operati ng at a current density of 0.699 $\mathrm{amp} / \mathrm{cm}^{2}$, and a steam utilization rate of $66.67 \%$. Each cell has an area of $225 \mathrm{~cm}^{2}$. The fluid conditions, flow rates, stream composition, and component operating parameters for this integrated configuration are summarized in Tables 1-3 for each of the locations shown in Figure 1.

The temperature, pressure, mass flow rates, and composition for selected key streams are displayed in Table 1. The heat and power flows are shown in Table 2. The thermal duty, the product of the overall heat transfer coefficient and heat transfer area (UA), and log-mean temperature difference (LMTD) of each heat exchanger are shown in Table 3.

As can be seen by the data, just over $90 \%$ of the power produced by the power cycle is used by the electrolysis cells. The circulators in the primary and secondary helium loops use $5 \%$ of the power. The duty of the IHX heat exchanger indicates that only $10 \%$ of the reactor heat is used directly by the process to heat the steam. The results also indicate the heat recuperation can reduce the heat load from the reactor by 72 $\mathrm{MW}_{\mathrm{t}}$.

Both the hydrogen and oxygen products have $99.9 \%$ purity with the $0.1 \%$ water. This study did not account for the energy of drying the hydrogen and oxygen. 


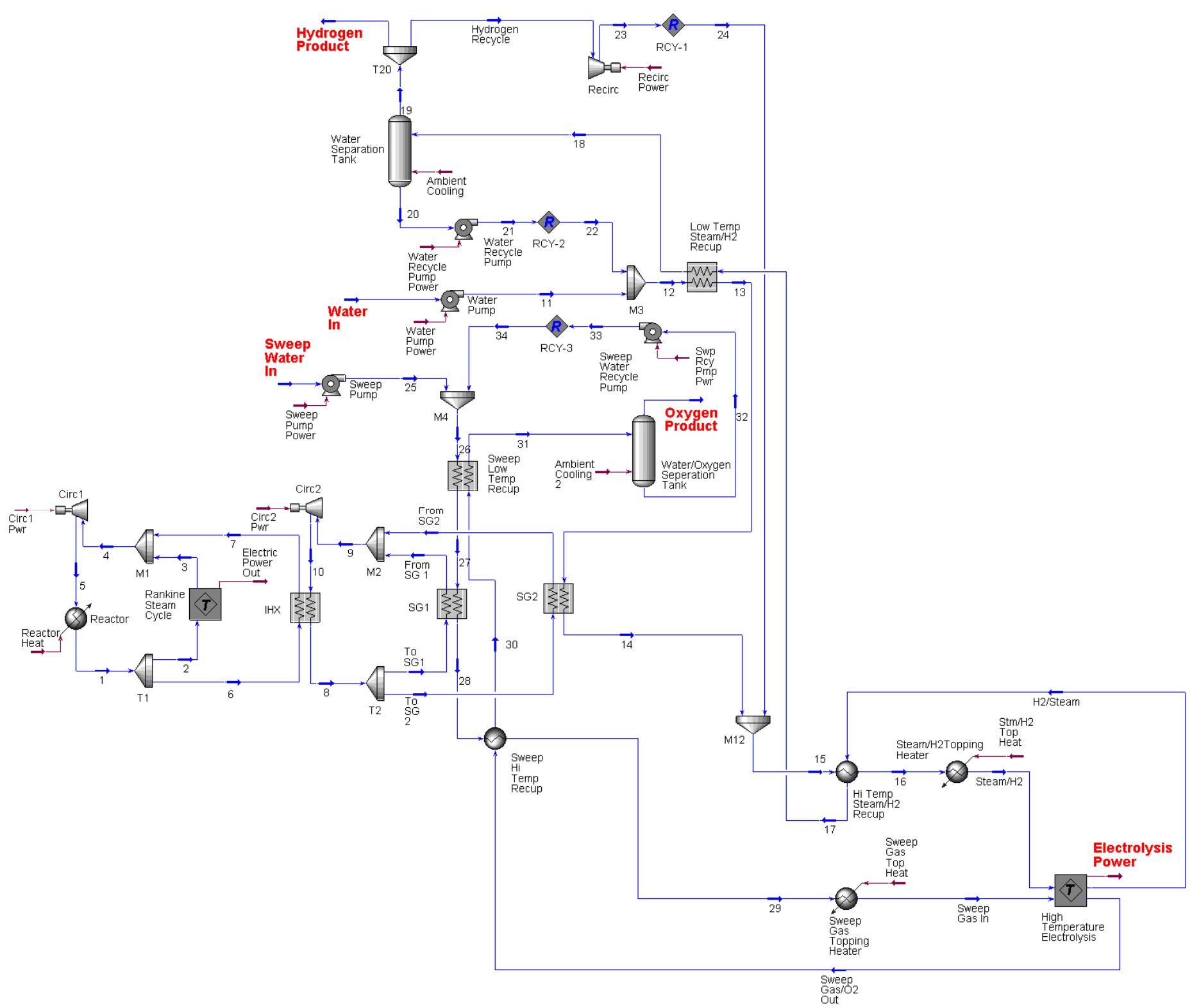

Figure 1. A process flow diagram of nuclear-integrated hydrogen production with high temperature electrolysis.

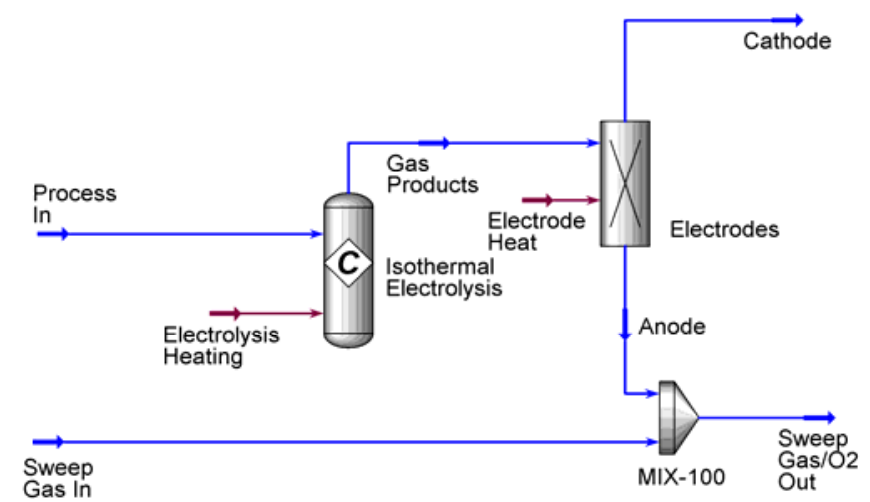

Figure 2. Process flow diagram of electrolysis process. 
Table 1. Selected stream results from analysis (see Figure 1)

\begin{tabular}{|c|c|c|c|c|c|c|c|}
\hline \multirow[t]{2}{*}{ Stream } & \multirow{2}{*}{$\begin{array}{c}\text { Mass Flow } \\
(\mathrm{kg} / \mathrm{s})\end{array}$} & \multirow{2}{*}{$\begin{array}{c}\text { Temperature } \\
\left({ }^{\circ} \mathrm{C}\right)\end{array}$} & \multirow{2}{*}{$\begin{array}{l}\text { Pressure } \\
(\mathrm{MPa})\end{array}$} & \multicolumn{4}{|c|}{ Molar Composition } \\
\hline & & & & $\mathrm{H}_{2}$ & $\mathrm{O}_{2}$ & $\mathrm{H}_{2} \mathrm{O}$ & $\mathrm{He}$ \\
\hline Water In & 16.5 & 26.6 & 0.101325 & & & 1.00 & \\
\hline Hydrogen Product & 1.85 & 26.0 & 4.80 & 0.999 & & .001 & \\
\hline Oxygen Product & 14.6 & 27.0 & 4.80 & & 0.999 & .001 & \\
\hline 5 & 270 & 322 & 7.07 & & & & 1.00 \\
\hline 1 & 270 & 750 & 7.00 & & & & 1.00 \\
\hline Steam/H2 & 25.0 & 800 & 5.00 & 0.100 & & 0.900 & \\
\hline H2/Steam & 10.4 & 800 & 5.00 & 0.700 & & 0.300 & \\
\hline Sweep Gas In & 8.22 & 800 & 5.00 & & 1.00 & & \\
\hline Sweep Gas/O2 Out & 22.8 & 800 & 5.00 & & 0.500 & 0.500 & \\
\hline
\end{tabular}

Table 2. Heat and power flows from analysis (see Figure 1)

\begin{tabular}{lcllc}
\multicolumn{2}{c}{ Heat Flow $\left(\mathrm{kW}_{\mathrm{t}}\right)$} & \multicolumn{2}{c}{ Power Flow $\left(\mathrm{kW}_{\mathrm{e}}\right)$} \\
\hline Reactor Heat & 600,000 & Electric Power Out & 249,000 \\
Stm/H2 Top Heat & 2,750 & Electrolysis Power & 226,000 \\
Sweep Gas Top Heat & 399 & Circ1 Pwr & 11,300 \\
Ambient Cooling & $-12,000$ & Circ2 Pwr & 1,530 \\
Ambient Cooling 2 & $-19,000$ & Recirc Power & 41.7 \\
& & Total Pump Power & 129 \\
\hline
\end{tabular}

Table 3. Heat exchanger data from analysis (see Figure 1)

\begin{tabular}{lrrr}
\multicolumn{1}{c}{ Heat Exchanger } & $\begin{array}{c}\text { Duty } \\
\left(\mathrm{kW}_{\mathrm{t}}\right)\end{array}$ & $\begin{array}{c}\mathrm{UA} \\
\left(\mathrm{W} /{ }^{\circ} \mathrm{C}\right)\end{array}$ & \multicolumn{1}{c}{\begin{tabular}{c}
\multicolumn{1}{c}{$\mathrm{C} \mathrm{C})$} \\
IHX
\end{tabular}} \\
59,900 & $2,395,000$ & 25.0 \\
SG1 & 6,790 & 254,000 & 26.8 \\
SG2 & 54,600 & 544,000 & 100.4 \\
Low Temp Steam/H2 Recup & 39,000 & 448,000 & 87.2 \\
Sweep Low Temp Recup & 24,400 & 258,000 & 94.8 \\
Hi Temp Steam/H2 Recup & 6,670 & 221,000 & 30.2 \\
Sweep Hi Temp Recup & 1,570 & 45,100 & 34.8 \\
\hline
\end{tabular}

\section{ECONOMIC ANALYSIS}

The economic viability of nuclear assisted hydrogen production was assessed using standard economic evaluation methods. The economics were evaluated for a Rankine steam cycle combined with a HTGR. The total capital investment (TCI), based on the total equipment costs, along with the variable and fixed operating costs were first calculated. The present worth of the annual cash $\mathrm{fl}$ ows (after taxes) is $\mathrm{t}$ hen calculated for the TCI, as well as the TCI at $+50 \%$ and $-30 \%$ of the HTGR cost, with the debt-to-equity ratios of $80 \%$ to $20 \%$.

The estimates of ca pital costs and op erating and maintenance costs assumed the nuclear plant was an " $\mathrm{n}^{\text {th }}$ of a kind", (NOAK). In other words, the estimates were based on the costs expected after the HTGR technology is integrated into an industrial application more than 10 times. The economic modeling calculations were based on two capital cost scenarios: a current best estimate of $\$ 2,000 / \mathrm{kWt}$ and a target of $\$ 1,400 / \mathrm{kW}_{\text {th }}$, where $\mathrm{kW}_{\text {th }}$ is the thermal rating of the plant. In comparison, light water nuclear reactor $\mathrm{c}$ osts are

approximately $\$ 1,250 / \mathrm{kW}_{\text {th }}$. Based on the two capital cost scenarios for HTGR technology, the nominal capital cost for a $600 \mathrm{MW}_{\text {th }}$ HTGR would be $\$ 1.2$ billion; the target capital cost would be $\$ 840$ million.

The capital costs and op eration and maintenance information for the Rankine steam cycle is based on the DOE National Energy Technology Laboratory (NETL) report, Cost and Performance Baseline for Fossil Energy Plant [6]. It was assumed that the pulve rized coal Ra nkine steam cycle developed in this report would be similar to the power cycle developed for a high-temperature gas-cooled reactor (HTGR). The costs from this report are 2006 dollars. The analysis is performed using 2009 dollars; therefore, the $\mathrm{C}$ hemical Engineering Plant Cost Index (CEPCI) was used to adjust the costs to 2009 dollars. The cost was also adjusted using the six-tenths factor rule using the power output as the capacity variables.

The capital installed costs for the HTSE process are based on a $\mathrm{r}$ eport by $\mathrm{H}$ arvego et al. [7] which assumes hydrogen 
production from a $600 \mathrm{MWt}$ high-temperature gas reactor with an outlet temperature of $900^{\circ} \mathrm{C}$. At that temperature, the power cycle efficiency is $53 \%$ with a corresponding hydrogen production rate of $2.4 \mathrm{~kg} / \mathrm{sec}$. For the current case, the power cycle efficiency is $44 \%$ with a hydrogen production flow rate of $1.85 \mathrm{~kg} / \mathrm{sec}$. The hydrogen production system in the Harvego report used air as the sweep gas, whereas this analysis used steam for the sweep gas. Heat exchanger costs in the HTSE process were adjusted in this analysis to account for the different sizes. Air sweep compressor costs (i ncluding intercoolers) were removed and a water pump for the sweep gas was added. The same installed cost factors found in the Harvego report were used to adjust the cost of the equipment. The costs from the Harvego report are 2005 costs; therefore CEPCI was used to adjust th e costs to 2009 dollars. Uninstalled costs are the basic cost of the equipment from the manufacturer. Installed costs are the uninstalled costs plus the additional materials and labor needed to place and install the equipment.

In the Harvego report, the cost of the elec trolysis cells is $\$ 200 / \mathrm{kWe}$, based on the power into the cells. This was derived from a 2007 goal of the Solid State Energy Conversion Alliance (SECA) for solid oxide fuel cells. The goal was set to $\$ 400 / \mathrm{kWe}$ for the fuel cells, but because solid oxide electrolysis cells run at twice th e voltage for the same current density, the el ectrolysis cells are half the cost. At a recent SECA conference, the goal for s olid oxide fuel cells has changed to $\$ 175 / \mathrm{kWe}$, which when halved for SOEC comes to $\$ 87.5 / \mathrm{kWe}[8]$. Consulting with HTE experts, a NOAK goal of $\$ 100 / \mathrm{kWe}$ was used for this study $[9,10]$.

The installed capital costs of the HTSE process without reactor and power cycle c osts is $\$ 66.4$ million. A \% breakdown of this cost is shown in Figure 3. The results show that $2 / 3$ of the cost is the electrolysis cells.

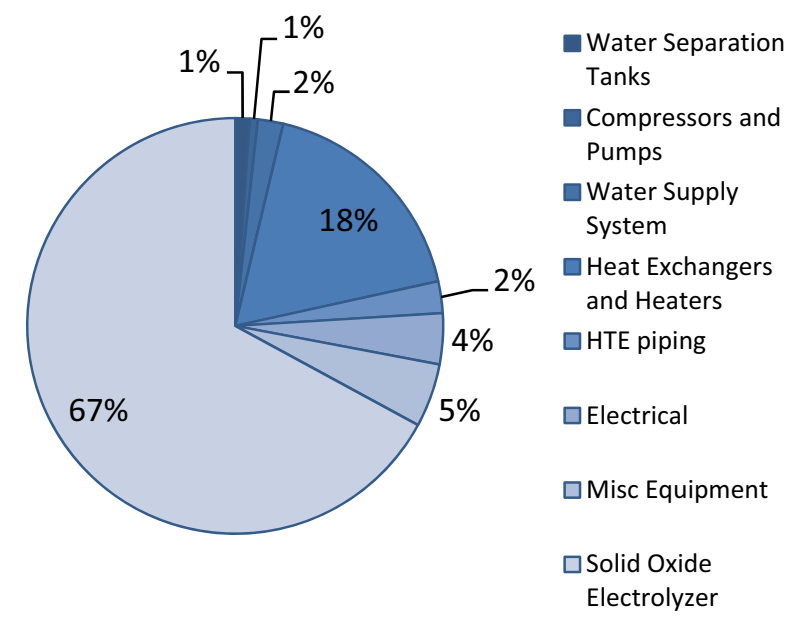

Figure 3. Installed capital costs of HTSE without reactor and power cycle costs.
The total capital investment (TCI) of the HTE connected to a $600 \mathrm{MWt}$ HTGR are calculated by multiplying the installed power cycle and HTE costs with a $10 \%$ engineering fee and a $18 \%$ contingency fee. The reactor cost already includes these fees. The HTE TCI also includes cooling towers and support capital like water, piping, instrument and controls, electrical systems and building and structures. The TCI for the nuclear reactor, power cycle, and the HTE process is $\$ 1.025$ billion, $\$ 184$ million, and $\$ 116$ million respectively. The total TCI is $\$ 1.324$ billion. The HTE process $m$ akes up $8.8 \%$ of the total TCI. If one assumes a $-30 \% \mathrm{TCI}$ for the reactor cost, the total TCI is $\$ 1.017$ billion.

Yearly revenues were estimated for low, average, and high prices for hydrogen, see Table 4.

Table 4. Annual revenues

\begin{tabular}{lccc}
\hline & $\begin{array}{c}\text { Price } \\
(\$ / \mathrm{kg})\end{array}$ & $\begin{array}{c}\text { Generated } \\
(\mathrm{kg} / \mathrm{s})\end{array}$ & \multicolumn{1}{c}{$\begin{array}{c}\text { Annual } \\
\text { Revenue }\end{array}$} \\
\hline Oxygen & 0.0459 & 14.6 & $\$ 19,400,000$ \\
Hydrogen-Low & 1.00 & 1.85 & $\$ 53,700,000$ \\
Hydrogen-Avg. & 3.00 & 1.85 & $\$ 161,000,000$ \\
Hydrogen-High & 5.00 & 1.85 & $\$ 269,000,000$ \\
\hline $\begin{array}{l}\text { Combined Annual } \\
\text { Revenue, low }\end{array}$ & & & $\mathbf{\$ 7 3 , 1 0 0 , 0 0 0}$ \\
$\begin{array}{l}\text { Combined Annual } \\
\text { Revenue, average }\end{array}$ & & & $\mathbf{\$ 1 8 0 , 0 0 0 , 0 0 0}$ \\
$\begin{array}{l}\text { Combined Annual } \\
\text { Revenue, high }\end{array}$ & & & $\mathbf{\$ 2 8 8 , 0 0 0 , 0 0 0}$ \\
\hline
\end{tabular}

Manufacturing cost is the sum of di rect and i ndirect manufacturing costs. Direct manufacturing costs for this project include the cost of raw $\mathrm{m}$ aterials, utilities, and operating labor and maintenance. Indirect manufacturing costs include estimates for the cost of overhead and insurance and taxes. ${ }^{9}$

The expected duration of the electrolysis cells for NOAK is 8 years. Assuming that one-eighth of the cells are replaced every year, and based on the $\$ 100 / \mathrm{kWe}$ cost of the cells, the yearly replacement cost is $\$ 2,714,310$.

Labor costs are assumed to be $1.15 \%$ of the total capital investment. Maintenance costs were assumed to be $3 \%$ of the total capital investment [11]. The power cycle and HTSE were not included in the TCI for operation and maintenance costs, as they were calculated separately. Taxes and insurance were assumed to be $1.5 \%$ of the total capital investment, excluding the HTGR, an overhead of $65 \%$ of the labor and maintenance costs was assumed, and royalties were assumed to be $1 \%$ of the coal or natural gas cost [11]. Error! Reference source not found. 5 provides the manufacturing costs for the HTSE case. Availability of the nuclear plant was assumed to be $92 \%$. 
Table 5. Annual manufacturing costs

\begin{tabular}{|c|c|c|c|c|}
\hline & \multicolumn{2}{|r|}{ Price } & Consumed & \multirow[t]{2}{*}{ Annual Cost } \\
\hline \multicolumn{4}{|l|}{ Direct Costs } & \\
\hline \multicolumn{5}{|l|}{ Materials } \\
\hline Water Clarification & 0.024 & $\$ / 1000$ gal & $629,136 \mathrm{gal} /$ day & $\$ 5,170$ \\
\hline Water Treatment & 1.315 & $\$ / 1000 \mathrm{gal}$ & $356,976 \mathrm{gal} /$ day & $\$ 158,000$ \\
\hline HTE Cell Replacements & 0.024 & $\$ / 1 \mathrm{~b} \mathrm{H}$ & $352,729 \mathrm{lb} /$ day $\mathrm{H}_{2}$ & $\$ 2,870,000$ \\
\hline Nuclear Fuel & 4.22 & \$/MWt-hr & $600 \mathrm{MWt}$ & $\$ 20,400,000$ \\
\hline \multicolumn{5}{|l|}{ Utilities } \\
\hline Water & 0.046 & $\$ / 1000 \mathrm{gal}$ & $629,136 \mathrm{gal} /$ day & $\$ 9,720$ \\
\hline Labor and Maintenance & & & & $\$ 3,270,000$ \\
\hline O\&M Nuclear & & & & $\$ 8,280,000$ \\
\hline \multicolumn{5}{|l|}{ Indirect Costs } \\
\hline Overhead & & & & $\$ 2,120,000$ \\
\hline Insurance and Taxes & & & & $\$ 4,490,000$ \\
\hline Manufacturing Costs & & & & $\$ 41,600,000$ \\
\hline
\end{tabular}

To assess the economics of the HTSE case, se veral economic indicators were calculated. The IRR for 1 ow, average, and high hydrogen selling prices was calculated. In addition, the fuel price $n$ ecessary for a retu rn of $10 \%$ was calculated. The following assumptions were made for the economic analyses:

- The plant startup year is five years after construction

- A construction period of five years for the nuclear plant that begins in year zero

- It is assumed that all reactors come online at the same time

- Percent capital invested for the HTGR is $20 \%$ per year

- Plant startup time is one year

- Operating costs are $85 \%$ of the total value during startup

- Revenues are $60 \%$ of the total value during startup

- The analysis period for the economic evaluation assumes an economic life of 30 years, excluding construction time (the model is built to accommodate up to 40 years)

- An inflation rate of $2.5 \%$ is assumed

- Debt-to-equity ratios of $80 \% / 20 \%$ are calcu lated as th is would be most consistent for an NOAK plant

- The interest rate on debt is assumed to be $8 \%$

- The repayment term on the loan is assumed to be 15 years

- The effective income tax rate is $38.9 \%$
- $\quad$ State tax is $6 \%$

- Federal tax is $35 \%$

- Modified Accelerated Cost-Recovery System (MACRS) depreciation is assumed.

To assess the IRR a nd present worth (PW) of each scenario, it is necessary to calculate the a fter tax cash $\mathrm{fl}$ ow (ATCF). To calculate the ATCF it is necessary to first calculate the revenues $\left(R_{k}\right)$, cash outflows $\left(E_{k}\right)$, sum of all noncash, or book, costs such as depreciation $\left(\mathrm{d}_{\mathrm{k}}\right)$, net income before taxes (NIBT), the effective income tax rate $(\mathrm{t})$, and the income taxes $\left(T_{k}\right)$, for each year $(k)$. The taxable income is revenue minus the sum of all cash outflow and noncash costs. Therefore the income taxes per year are defined as follows:

$$
T_{k}=t\left(R_{k}-E_{k}-d_{k}\right)
$$

Depreciation for the economic calculations was calculated using a standard MACRS depreciation method with a property class of 15 years. Depreciation was assumed for the total capital investment over the five year construction schedule, including inflation.

The ATCF is then the sum of the before tax cas h flow (BTCF) minus the income taxes owed. Note that the expenditures for capital are not taxed but are included in the BTCF each year the re is a capital expe nditure $\left(\mathrm{C}_{\mathrm{k}}\right)$; this includes the equity capital and the debt principle. The BTCF is defined as follows:

$$
B T C F_{k}=R_{k}-E_{k}-C_{k}
$$

The ATCF can then be defined as:

$$
A T C F_{k}=B T C F_{k}-T_{k}
$$


The IRR method is the most widely used rate of return method for performing engineering economic analyses. This method solves for the interest rate that equates the equivalent worth of an alternative's cash inflows to the equivalent worth of cash outflows (after tax cash flow), i.e., the interest rate at which the PW is zero. The resulting interest is the IRR (i'). For the project to be economically viable, the calculated IRR must be greater than the desired minimum annual rate of return (MARR).

$$
P W\left(i^{\prime} \%\right)=\sum_{k=0}^{N} A T C F_{k}\left(1+i^{\prime}\right)^{-k}=0
$$

IRR calculations were performed for an $80 \% / 20 \%$ debt-toequity ratio and for $-30 \%$ TCI for the HTGR at low, average, and high prices. In addition, the price of hydrogen necessary for an IRR of $10 \%$ and a PW of zero was calculated for each case at each debt-to-equity ratio. The IRR and hydrogen price required (for an IRR of 10\%) was solved for using the Goal Seek function in Excel. Tab le 6 shows the results of this analysis.

Table 6 . IRR results for $80 \% / 20 \%$ debt-to-equity ratio.

\begin{tabular}{ccccc}
\hline & \multicolumn{2}{c}{ TCI $-30 \%$} & HTGR & \multicolumn{2}{c}{ TCI } \\
IRR & $\$ / \mathrm{kg}$ & IRR & $\$ / \mathrm{kg}$ \\
\hline \multirow{4}{*}{ HTE } & \multicolumn{3}{c}{$\$ 1,016,751,979$} & \multicolumn{2}{c}{$\$ 1,324,251,979$} \\
& 13.25 & $\$ 3.00$ & 9.86 & $\$ 3.00$ \\
& 22.59 & $\$ 5.00$ & 17.72 & $\$ 5.00$ \\
& 10.00 & $\$ 2.41$ & 10.00 & $\$ 3.03$ \\
\hline
\end{tabular}

\section{CONCLUSIONS}

An analysis was performed for the production of hydrogen using nuclear-integrated high temperature electrolysis. A 600 $\mathrm{MWt}$ high temperature gas reactor with a $750{ }^{\circ} \mathrm{C}$ outlet temperature can produce $1.85 \mathrm{~kg} / \mathrm{s}$ of hydrogen and $14.6 \mathrm{~kg} / \mathrm{s}$ of oxygen. At an IR R of $10 \%$ and a debt-to-equity ratio of $80 \% / 20 \%$, the cost of hydrogen production is $\$ 3.03 / \mathrm{kg}$ of hydrogen produced.

The current method of hydrogen production is through the steam/methane reform process (SMR). T he price of SMR produced hydrogen is linked closely with the cost of the natural gas feed. Based on a natural gas price of $\$ 5.40$, (the average price in 2009), the pri ce of hydrogen production for SMR is $\$ 1.75[12,13]$. Although the cost of hydrogen production is less, the SMR process releases greenhouse gases.

At higher reactor outlet temperatures, the power cycle efficiency increases which directly increases the hydrogen production efficiency. At reactor outlet te mperatures of $900^{\circ} \mathrm{C}$, the power cycle effic iency can exceed $50 \%$. At these higher temperatures it is hoped that the cost of hydrogen production will be more like the cost of SMR production.

Finally, if the cost of the reactor can be reduced, the cost of hydrogen production via HTE improves greatly. At the $-30 \%$
HTR TCI, the cost of hydrogen production is $\$ 2.41 / \mathrm{kg}$ of hydrogen.

\section{ACKNOWLEDGMENTS}

This work was supported by the Idaho National Laboratory, Next Generation Nuclear Plant and by the U.S. Department of Energy, Office of Nuclear Energy.

\section{COPYRIGHT STATEMENT}

This manuscript has been authored by Battelle Energy Alliance, LLC under Contract No. DE-AC07-05ID14517 with the U.S. Department of Energy. The United States Government retains and the publisher, by accepting the article for publication, acknowledges that the United States Government retains a no nexclusive, paid-up, irrevocable, world-wide license to publish or reproduce the published form of this manuscript, or allow others to do so, for United States Government purposes.

\section{REFERENCES}

1. McKellar, M. G., O’Brien, J. E., Harvego, E. A., and Herring, J. S., “Optimized Flow Sheet for a Reference Commercial-Scale Nuclear-Driven High-Temperature Electrolysis Hydrogen Production Plant, INL/EXT-0713573, November 2007.

2. Harvego, E. A., McKellar, M. G., S ohal, M. S., O'Brien, J. E., and Herring, J. S., "Re ference Design and Economic Analysis for a Nuclear-Driven HighTemperature-Electrolysis Hydrogen Production Plant," ASME $2^{\text {nd }}$ International Conference on Energy Sustainability, paper\# 54206, Jacksonville, FL, August 10-14, 2008.

3. Varrin, R. D., Reifsneider, K., Scott, D. S., Irving, P., and Rolfson, G., "NGNP Hydrogen Technology DownSelection; Results of the Independent Review Team Evaluation," Dominion Engineering report\# R-691700-01, August, 2009.

4. HYSYS.Plant version 2. 2.2 (Build 3806) from Hyprotech Ltd.

5. O'Brien, J. E., Stoots, C. M., and Hawkes, G. L., "Comparison of a One-Dimensional Model of a HighTemperature Solid-Oxide Electrolysis Stack with CFD and Experimental Results," Proceedings, 2005 ASME International Mechanical Engineering Congress and Exposition, Nov. 5 - 11, Orlando.

6. Klara, Julianne M., 2007, "Cost and Pe rformance Baseline for Fo ssil Energy Plants Study, Volume 1: Bituminous Coal and Nat ural Gas t o Electricity," DOE/NETL-2007/1287, May 2007.

7. Harvego, E. A., M. G. McKellar, M. S. Sohal, J. E. O'Brien, and J. S. Herring, 2008, Economic Analysis of the Reference Design for a Nuclear-Driven HighTemperature-Electrolysis Hydrogen Production Plant, INL/EXT-08-13799, January 2008.

8. Surdoval, Wayne, 2009, "Clean Economic Energy in a Carbon Challenge World," Presentation at $10^{\text {th }}$ Annual 
Solid State Energy Conversion Alliance (SECA)

Workshop, Plenary Session, July 14-16, 2009,

Pittsburgh, PA, viewed at

http://www.netl.doe.gov/publications/proceedings/09/s

eca/index.html.

9. Personal communication with Dr. Stephen Herring, High Temperature Electrolysis project 1 ead, Idaho National Laboratory, Jan 22, 2010.

10. Personal communication with Dr. Joseph Hartvigsen, Senior Engineer, SOFC and Hydrogen Technologies, Ceramatec Inc., Jan 21, 2010.

11. Jones, David S. J., and Peter R. Rujad o, 2006, Handbook of Petroleum Processing. Dordrecht: Spring, 2006.

12. U.S. Energy Information Administration, Independent Statistics and Analysis,Natural Gas Navigator, http://tonto.eia.doe.gov/dnav/ng/hist/n3035us3m.htm

13. "The Impact of Increased Use of $\mathrm{H}$ ydrogen on Petroleum Consumption and Carbon Dioxide Emissions", Energy Information Administration, Department of E nergy, Report SR/OIAFCNEAF/2008-04, August 2008. 